\title{
Umbilical Cord Blood Gas Analysis, Obstetric Performance and Perinatal Outcome
}

\section{Gasometria do cordão umbilical, atuação obstétrica e desfecho neonatal}

\author{
Cátia Sofia Ferreira ${ }^{1}$ Ângela Melo ${ }^{1}$ Ana Helena Fachada ${ }^{1}$ Helena Solheiro ${ }^{1}$ Nuno Nogueira Martins ${ }^{1}$ \\ ${ }^{1}$ Department of Obstetrics and Gynecology, Centro Hospitalar \\ Tondela-Viseu, Viseu, Portugal \\ Address for correspondence Cátia Sofia Ferreira, MD, Serviço de \\ Ginecologia e Obstetrícia, Centro Hospitalar Tondela-Viseu, \\ Rev Bras Ginecol Obstet 2018;40:740-748 \\ Avenida Rei D. Duarte, 3504-509, Viseu, Portugal \\ (e-mail: csf0301@gmail.com).
}

\begin{abstract}
Keywords

- Umbilical Cord Blood Gas Analysis

- delivery

- morbidity

- neonatology
\end{abstract}

Objective To analyze if umbilical artery $\mathrm{pH}\left(\mathrm{pH}_{\mathrm{ua}}\right) \leq 7.00$ and umbilical artery blood deficit $\left(\mathrm{BD}_{\text {ua }}\right) \geq 12.00 \mathrm{mmol} / \mathrm{L}$ are good predictors of adverse neonatal outcomes.

Methods This was an observational, longitudinal and retrospective cohort study, conducted at the department of obstetrics and gynecology of Centro Hospitalar Tondela Viseu between September 2013 and September 2015. Total cohort and subgroup analysis were performed: group A-women with umbilical cord blood gas analysis (UCBGA) performed for non-reassuring fetal cardiotocographic patterns, placental abruption, or shoulder dystocia; and group B-all the others. Assays were made with the software SPSS for Windows, Versions 20.0 and 21.0 (IBM Corp., Armonk, NY, USA).

Results A total of $428 \mathrm{UCBGAs}$ met the inclusion criteria. The group analysis revealed an association between group $A$ and pHua $\leq 7.00$, as well as between BDua $\geq 12.00$ $\mathrm{mmol} / \mathrm{L}$ and $1 \mathrm{st}$ minute Apgar score $\leq 4(p=0.011)$. After the application of the logistic regression models in the total cohort analysis, $\mathrm{pH}_{\mathrm{ua}} \leq 7.00$ had an impact in the occurrence of acute neonatal hypoxia (odds ratio [OR]: 6.71; 95\% confidence interval $[\mathrm{Cl}]: 1.21-37.06 ; p=0.029)$; multiparous women had a higher risk of delivering a newborn with first minute Apgar score $\leq 4$ and acute neonatal hypoxia (OR: 5.38; 95\% Cl: 1.35-21.43; $p=0.017$; and OR: 2.66 ; 95\% Cl: 1.03-6.89, $p=0.043$, respectively); women who had urologic problems during pregnancy had a higher risk of delivering a newborn with 5th minute Apgar score $\leq 7$ (OR: 15.17; 95\% Cl: 1.29-177.99; $p=0.030)$; and shoulder dystocia represented a 15 times higher risk of acute neonatal hypoxia (OR: 14.82; 95\% Cl: 2.20-99.60; $p=0.006$ ).

Conclusion The $\mathrm{pH}_{\text {ua }}$ and the $\mathrm{BD}_{\text {ua }}$ are predictors of adverse neonatal outcome, and UCBGA is a useful tool for screening newborns at risk. Universal UCBGA should be considered for all deliveries, as it is an accurate screening test for neonatal hypoxia. received

December 13, 2017

accepted

August 9, 2018

published online

October 30, 2018
DOI https://doi.org/

$10.1055 / \mathrm{s}-0038-1675187$ ISSN $0100-7203$.
Copyright $\odot 2018$ by Thieme Revinter

Publicações Ltda, Rio de Janeiro, Brazil
License terms

(c) (1) 


\section{Resumo}

\section{Palavras-chave}

- gasometria do cordão umbilical

- parto

- morbilidade

- neonatologia
Objetivo Avaliar se o $\mathrm{pH}$ da artéria umbilical $\left(\mathrm{pH}_{\mathrm{ua}}\right) \leq 7,00$ e o déficit de bases da artéria umbilical $\left(\mathrm{BD}_{\text {ua }}\right) \geq 12,00 \mathrm{mmol} / \mathrm{L}$ são preditores de desfechos neonatais adversos.

Métodos Estudo observacional, longitudinal e retrospectivo, realizado no Serviço de Ginecolocgia e Obstetrícia do Centro Hospitalar Tondela Viseu durante o período de setembro de 2013 a setembro de 2015 . Foi realizada a análise de toda a coorte e de dois subgrupos: grupo A-mulheres cuja gasometria do cordão umbilical (UCBGA, na sigla em inglês) foi realizada por traçado cardiotocográfico não tranquilizador, descolamento prematuro de placenta normalmente inserida, ou distócia de ombros; e grupo B -todas as outras. A análise estatística foi realizada com o programa SPSS for Windows, Versões 20.0 e 21.0 (IBM Corp., Armonk, NY, USA)

Resultados Um total de 428 UCBGAs cumpriram os critérios de inclusão. A análise de grupo revelou uma associação entre o grupo $\mathrm{A}$ e $\mathrm{pH}_{\mathrm{ua}} \leq 7,00(p=0,002)$, e entre $\mathrm{BD}_{\text {ua }}$ $\geq 12,00 \mathrm{mmol} / \mathrm{L}$ e índice de Apgar ao $1^{\circ}$ minuto $\leq 4(p=0,011)$. Após a aplicação dos modelos de regressão logística na análise da coorte total, $\mathrm{pH}_{\text {ua }} \leq 7.00$ teve impacto na ocorrência de hipóxia neonatal aguda (razão de probabilidade [RP]: 6,71; 95\% índice de confiança [IC]: 1,21-37,06; $p=0,029$ ); verificou-se maior risco de recém-nascido com índice de Apgar ao $1^{\circ}$ minuto $\leq 4$ e hipóxia neonatal aguda nas multíparas (RP: 5,38; 95\% IC: $1,35-21, .43 ; p=0,017$; e RP: 2,66; $95 \%$ IC: $1,03-6,89 ; p=0,043$, respectivamente); e de recém-nascido com índice de Apgar ao quinto minuto $\leq 7$ nas mulheres com problemas urológicos na gravidez (RP: 15,17; 95\% IC: 1,29-177,99; $p=0,030$ ); e a ocorrência de distócia de ombros aumentou 15 vezes o risco de hipóxia neonatal aguda (RP: 14,82; 95\% IC: 2,20-99,60; $p=0,006$ ).

Conclusão $\mathrm{O} \mathrm{pH}_{\mathrm{ua}}$ e o $\mathrm{BD}_{\text {ua }}$ são preditores de desfecho neonatal adverso, e a UCBGA é uma ferramenta útil no rastreio dos recém-nascidos em risco. A realização universal de UCBGA deve ser considerada em todos os partos, visto ser um teste de rastreio objetivo de hipóxia neonatal.

\section{Introduction}

Fetal and neonatal acidemia are associated with several adverse neonatal outcomes. ${ }^{1-7}$ These outcomes include low Apgar scores, respiratory distress syndrome (RDS), hypoxicischemic encephalopathy (HIE), seizures, intraventricular hemorrhage, sepsis, and death. ${ }^{1-7}$ Determining the time of injury is essential to understand the mechanisms underlying these outcomes and can have important medico-legal implications. The umbilical cord blood gas analysis (UCBGA) is an objective and validated tool to evaluate the oxygenation and metabolic status of the newborn at birth. ${ }^{1-6}$ If the umbilical artery $\mathrm{pH}\left(\mathrm{pH}_{\mathrm{ua}}\right)$ is $\leq 7.00$ and the umbilical artery base deficit $\left(\mathrm{BD}_{\mathrm{ua}}\right)$ is $\geq 12.00 \mathrm{mmol} / \mathrm{L}$, there is an established diagnosis of neonatal metabolic acidemia, and the risk of neurologic sequelae is higher in this setting. ${ }^{1-3,6,8}$ Although the $\mathrm{pH}_{\mathrm{ua}}$ is a well-established marker of neonatal hypoxia, the $\mathrm{BD}_{\mathrm{ua}}$ is not. The $\mathrm{BD}_{\mathrm{ua}}$ is useful in distinguishing between respiratory and metabolic umbilical artery acidemia. ${ }^{1-6,9}$ This distinction is important because respiratory acidosis is not usually associated with complications for the newborn. ${ }^{10,11}$ Performing an UCBGA remains a good screening test for newborns at risk of poor neurologic outcome. ${ }^{4,12,13}$ It can be recommended for all high-risk deliveries. ${ }^{4,12}$ The Royal College of Obstetricians and
Gynaecologists recommends that an UCBGA should be performed in all cesarean or operative vaginal deliveries executed due to fetal compromise. ${ }^{12}$ The American College of Obstetricians and Gynecologists states that an UCBGA should be performed after any delivery in which a fetal metabolic abnormality is suspected. ${ }^{13}$ The main aim of the present study was to analyze whether $\mathrm{pH}_{\mathrm{ua}} \leq 7.00$ and $\mathrm{BD}_{\mathrm{ua}} \geq 12.00 \mathrm{mmol} / \mathrm{L}$ were good predictors of adverse neonatal outcomes. The secondary aim of the present study was to determine if there was any association between these outcomes and other potential risk factors that could act as confounders.

\section{Methods}

This was an observational, longitudinal and retrospective cohort study conducted between September 2013 and September 2015, at the department of obstetrics and gynecology of Centro Hospitalar Tondela Viseu. All women who delivered in the labor ward and had a valid UCBGA according to the local protocol ( - Table $\mathbf{1}$ ) were included.

All cases of multiple pregnancies, fetal growth restrictions, preeclampsia, intrapartum fever, preterm delivery, pelvic vaginal delivery, antenatal or postnatal diagnosis of cardiac malformations and low birthweight newborn were excluded 
Table 1 Indications for performing umbilical cord blood gas analysis

\begin{tabular}{|l|}
\hline Maternal thyroid disease \\
\hline Assisted reproductive technology \\
\hline Multiple pregnancy \\
\hline Fetal growth restriction and/or another fetal pathology \\
\hline Non-reassuring fetal cardiotocographic pattern \\
\hline Intrapartum fever \\
\hline Preterm delivery \\
\hline Instrumental delivery \\
\hline Low Apgar score $(<8$ at any minute) or decreasing Apgar score \\
\hline Low birthweight $(<2,500 \mathrm{~g})$ or small newborn for gestational age \\
\hline
\end{tabular}

(-Fig. 1). Valid samples had a difference of $\geq 0.03$ between $\mathrm{pH}_{\mathrm{ua}}$ and umbilical vein $\mathrm{pH}$.

The total cohort data was analyzed. A subsequent group analysis was also done: group A, which included the UCBGA performed for non-reassuring fetal cardiotocography (CTG) patterns or placental abruption, and group $\mathrm{B}$, which included all the remaining cases. The purpose of the group analysis was to check for a stronger association of $\mathrm{pH}_{\mathrm{ua}} \leq 7.00$ and BDua $\geq 12.00 \mathrm{mmol} / \mathrm{L}$ in group $\mathrm{A}$ and to find out if the predictive value of $\mathrm{pH}_{\mathrm{ua}} \leq 7.00$ and $\mathrm{BDua} \geq 12.00 \mathrm{mmol} / \mathrm{L}$ for adverse neonatal outcomes was stronger in group $A$ than

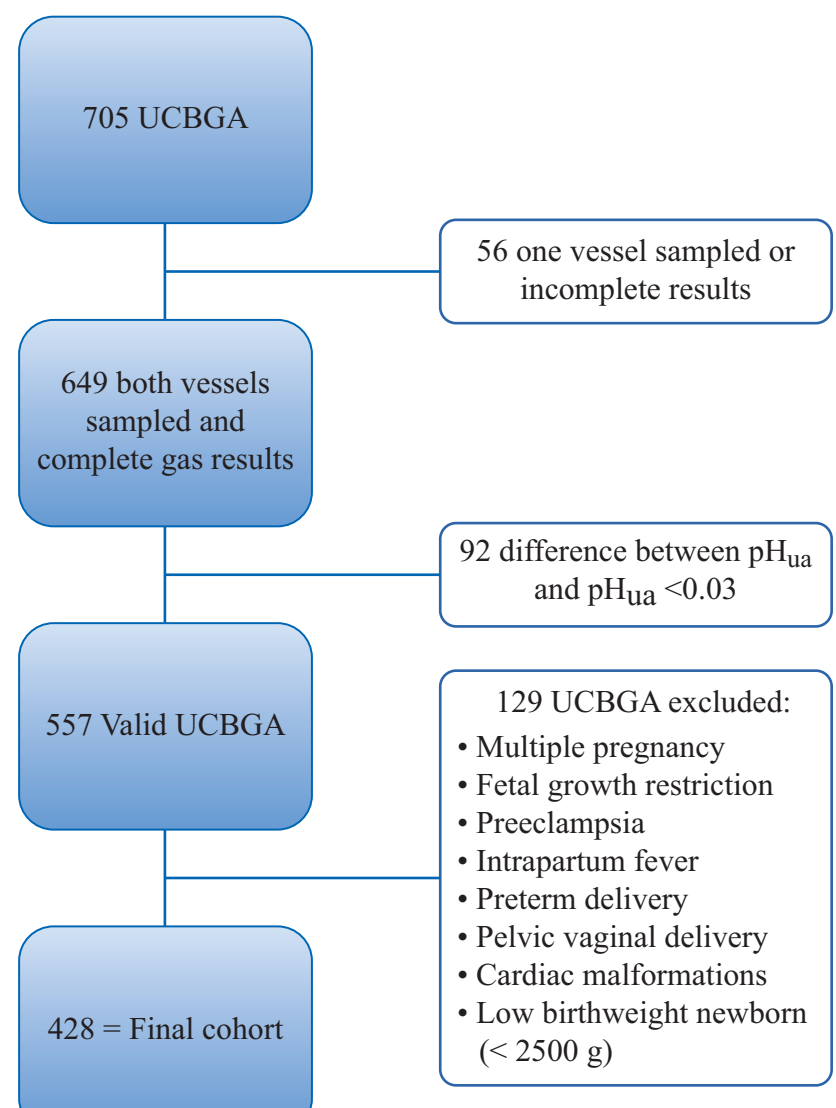

Fig. 1 Study's sample exclusion criteria. in group B. Data was collected through the review of electronic and manuscript clinical files.

In the UCBGA technique used, the cord was triple-clamped immediately after delivery with an in-between length of $\sim 10$ to $20 \mathrm{~cm}$. The distal segment was then cut and placed over a table, where the blood samples were taken, first from the artery and then from the vein. Preheparinised syringes (Pro-Vent ${ }^{\circledR}$, Smiths medical ASD, Inc., Keene, New Hampshire, USA) were used. The samples were analyzed within a maximum of 30 minutes at the hospital central laboratory, and the results were made electronically available to the team immediately after.

Two neonatal outcome predictors were analyzed: $\mathrm{pH}_{\mathrm{ua}}$ $\leq 7.00$ and $\mathrm{BD}_{\mathrm{ua}} \geq 12.00 \mathrm{mmol} / \mathrm{L}$.

The adverse neonatal outcomes that were analyzed were:

1. First minute Apgar Score (1'AS) $\leq 4$;

2. Fifth minute Apgar Score (5'AS) $\leq 7$;

3. Acute neonatal hypoxia (ANH)-condition in which the newborn has been exposed to intrapartum reversible asphyxia, without documented HIE;

4. Hypoxic-ischemic encephalopathy-disturbed neurologic function in the earliest days of life, manifested by a reduced level of consciousness or seizures, often accompanied by difficulty at initiating and maintaining respiration, and by depression of tone and reflexes, in a newborn with one or more of the following: (a) a sentinel hypoxic or ischemic event occurring immediately before or during labor and delivery; (b) $\mathrm{pH}_{\mathrm{ua}} \leq 7.00$ and/or $\mathrm{BD}_{\mathrm{ua}} \geq 12.00 \mathrm{mmol} / \mathrm{L}$; (c) presence of multisystem organ failure consistent with HIE;

5. Neonatal convulsion;

6 . Hyaline membrane disease or respiratory distress syndrome type I (RDS I);

7. Transient tachypnea of the newborn or respiratory distress syndrome type II (RDS II);

8. Meconium aspiration syndrome-respiratory distress at or shortly after birth in the presence of evidence of meconium-stained amniotic fluid on infant and characteristic radiographic features (hyperinflation of the lungs with flattening of the diaphragm, diffuse patchy densities alternating with areas of expansion, pneumothorax, and pneumomediastinum);

9. Neonatal bradycardia;

10. Neonatal sepsis-a clinically ill newborn with isolation of pathogenic bacteria from blood culture or, in its absence, with laboratory test results consistent with infection (leukopenia or leukocytosis, immature to total neutrophil ratio $>0.16$; immature to mature neutrophil ratio $>0.2$; C-reactive protein $>10-15 \mathrm{mg} / \mathrm{L}$ and/or procalcitonin $>3$ $\mathrm{ng} / \mathrm{mL}$ ); and after exclusion of other infectious causes.

The Analysis was performed using the software SPSS for Windows, Versions 20.0 and 21.0 (IBM Corp., Armonk, NY, USA). Maternal and newborn demographic data and the incidence of outcomes were compared between the groups with the chi-squared test and the Fisher exact test. The association between each outcome and the predictors was made through univariate analysis, calculating the odds ratio (OR) with a 95\% confidence interval $(\mathrm{CI})$. The Wald test was applied to the outcomes with a statistically 
Table 2 Characteristics of the cohort

\begin{tabular}{|c|c|c|c|c|c|c|c|}
\hline \multirow[t]{2}{*}{ Variables } & \multicolumn{2}{|c|}{ Total cohort } & \multicolumn{2}{|c|}{ Group A } & \multicolumn{2}{|c|}{ Group B } & \multirow[b]{2}{*}{ p-value } \\
\hline & $n$ & $\%$ & $n$ & $\%$ & $n$ & $\%$ & \\
\hline \multicolumn{7}{|l|}{ Maternal age (years old) } & \multirow[t]{7}{*}{0.957} \\
\hline$\leq 19$ & 10 & 2.3 & 1 & 0.6 & 9 & 3.6 & \\
\hline $20-24$ & 36 & 8.4 & 16 & 9.1 & 20 & 7.9 & \\
\hline $25-29$ & 117 & 27.3 & 52 & 29.7 & 65 & 25.7 & \\
\hline $30-34$ & 158 & 36.9 & 62 & 35.4 & 96 & 37.9 & \\
\hline $35-37$ & 57 & 13.3 & 27 & 15.4 & 30 & 11.9 & \\
\hline$\geq 38$ & 50 & 11.7 & 17 & 9.7 & 33 & 13.0 & \\
\hline \multicolumn{7}{|l|}{ Parity } & \multirow[t]{3}{*}{0.092} \\
\hline Nulliparous & 291 & 68.0 & 111 & 63.4 & 180 & 71.1 & \\
\hline Multiparous & 137 & 21.0 & 64 & 36.6 & 73 & 28.9 & \\
\hline \multicolumn{7}{|l|}{ Insulin treated gestational diabetes } & \multirow[t]{3}{*}{0.714} \\
\hline No & 409 & 95.6 & 168 & 96.0 & 241 & 95.3 & \\
\hline Yes & 19 & 4.4 & 7 & 4.0 & 12 & 4.7 & \\
\hline \multicolumn{7}{|l|}{ Non-insulin treated gestational diabetes } & \multirow[t]{3}{*}{1.000} \\
\hline No & 419 & 97.9 & 171 & 97.7 & 248 & 98.0 & \\
\hline Yes & 9 & 2.1 & 4 & 2.3 & 5 & 2.0 & \\
\hline \multicolumn{7}{|l|}{ Gestational hypertension } & \multirow[t]{3}{*}{0.481} \\
\hline No & 420 & 98.1 & 173 & 97.7 & 247 & 97.6 & \\
\hline Yes & 8 & 1.9 & 2 & 2.3 & 6 & 2.4 & \\
\hline \multicolumn{7}{|l|}{ Urologic problems during pregnancy } & \multirow[t]{3}{*}{0.164} \\
\hline No & 423 & 98.8 & 171 & 97.7 & 252 & 99.6 & \\
\hline Yes & 5 & 1.2 & 4 & 2.3 & 1 & 0.4 & \\
\hline \multicolumn{7}{|l|}{ Oligohydramnios } & \multirow[t]{3}{*}{0.481} \\
\hline No & 420 & 98.1 & 173 & 98.9 & 247 & 97.6 & \\
\hline Yes & 8 & 1.9 & 2 & 1.1 & 6 & 2.4 & \\
\hline \multicolumn{7}{|l|}{ Gestational age at birth (gestational weeks) } & 0.667 \\
\hline $37-38$ & 75 & 17.5 & 29 & 16.6 & 46 & 18.2 & \\
\hline$\geq 39$ & 353 & 82.5 & 146 & 83.4 & 207 & 81.8 & \\
\hline Delivery & & & & & & & 0.000 \\
\hline Normal vaginal & 25 & 5.8 & 9 & 5.1 & 16 & 6.3 & \\
\hline Vacuum & 239 & 55.8 & 80 & 55.8 & 159 & 62.8 & \\
\hline Forceps & 30 & 7.0 & 9 & 5.1 & 21 & 8.3 & \\
\hline Caesarean section & 134 & 31.3 & 175 & 44.0 & 57 & 22.5 & \\
\hline UCBGA motive & & & & & & & 0.000 \\
\hline Control & 14 & 3.3 & 0 & 0.0 & 14 & 5.5 & \\
\hline Assisted reproductive technology & 1 & 0.2 & 0 & 0.0 & 1 & 0.4 & \\
\hline Small for gestational age newborn & 1 & 0.2 & 0 & 0.0 & 1 & 0.4 & \\
\hline Instrumental delivery & 235 & 54.9 & 0 & 0.0 & 235 & 92.9 & \\
\hline Non-reassuring fetal CTG pattern & 171 & 40.0 & 171 & 97.7 & 0 & 0.0 & \\
\hline Placental abruption & 4 & 0.9 & 4 & 2.3 & 0 & 0.0 & \\
\hline Shoulder dystocia & 2 & 0.5 & 0 & 0.0 & 2 & 0.8 & \\
\hline Gender & & & & & & & 0.015 \\
\hline Female & 184 & 43.0 & 63 & 36.0 & 121 & 47.8 & \\
\hline Male & 244 & 57.0 & 112 & 64.0 & 132 & 52.2 & \\
\hline Birthweight (grams) & & & & & & & 0.013 \\
\hline$<4,000$ & 415 & 97.0 & 174 & 99.4 & 241 & 95.3 & \\
\hline$\geq 4,000$ & 13 & 3.0 & 1 & 0.6 & 12 & 4.7 & \\
\hline Total & 428 & 100.0 & 175 & 100.0 & 253 & 100.0 & \\
\hline
\end{tabular}

Abbreviations: CTG, cardiotocographic; UCBGA, umbilical cord blood gas analysis. 
significantly association with one or both predictors to check if the ORs were different between the groups and to decide whether to analyze them separately for each group or in the total cohort. Independent predictors of three outcomes were obtained with two multivariate analyses with multiple logistic regressions. The multivariate analysis models were tested with the Hosmer and Lemeshow test and receiver operating characteristic curves. The possible confounders tested were: (a) maternal age ( $<35$ versus $\geq 35$ years old); (b) parity (nulliparity versus multiparity); (c) gestational age (37-38 versus $\geq 39$ weeks); (d) presence of insulin treated and non-insulin treated gestational diabetes; (e) urologic problems during pregnancy (such as recurrent cystitis, pyelonephritis, hydronephrosis, and hydroureter); (e) presence of oligohydramnios; (f) mode of delivery; ( $\mathrm{g}$ ) shoulder dystocia at birth; (h) newborn gender; (i) newborn birthweight $(<4,000 \mathrm{~g}$ versus $\geq 4,000 \mathrm{~g}$ ); $(\mathrm{j})$ presence of neonatal sepsis; and $(\mathrm{k})$ presence of neonatal seizures. The significance level was $5 \%(p<0.05)$.

The Ethics Committee for Health of the authors' institution approved the present study under the reference number 21/4/2017/1, on April 21st, 2017.

\section{Results}

The main characteristics of the cohort are listed in - Table 2 .

The mean maternal age did not differ significantly between the groups; it was $31.0 \pm 5.1$ and $30.8 \pm 5.3$ years old in groups A and $\mathrm{B}$, respectively $(p=0.809)$. In addition, there were no major differences in the distribution of maternal age between the age groups ( $p=0.957)$. In both groups, the majority of women was nulliparous $(63.4 \%$ in group A versus $71.1 \%$ in group $B, p=0.092$ ). Few women had a diagnosis of gestational diabetes, gestational hypertension, or urologic problems during pregnancy. Only two women in group A and six women in group B had oligohydramnios $(p=0.481)$.

The mean gestational age at delivery was similar between the groups (39.45 \pm 1.02 weeks in group A versus $39.36 \pm 1.06$ weeks in group $B ; p=0.380$ ), and most women delivered at 39 weeks or beyond (83.4\% in group A versus $81.8 \%$ in group B; $p=0.667)$. Vacuum assisted delivery was the most common birth type in both groups (45.7\% versus $62.8 \%$ in groups A and B, respectively) and the caesarean rate was higher in group $A$
(44.4\% versus $22.5 \% ; p=0.000$ ). The most frequent reason to perform an UCBGA in group A was a non-reassuring fetal CTG pattern $(n=171 ; 97.7 \%)$, while in group B it was instrumental delivery ( $n=235 ; 92.9 \%)$. The women in group A were more likely to have male newborns (64.0\% versus $52.2 \%$; $p=0.015$ ), although the male gender predominated in both groups. The mean birthweight was higher in group B $(3,254.14 \pm 337.48$ versus $3,345.85 \pm 407.09 \mathrm{~g} ; p=0.012$ ) and the women in group $\mathrm{B}$ were more likely to have macrosomic newborns (0.6\% versus $4.7 \% ; p=0.013$ ).

In group $\mathrm{A}$, the mean $\mathrm{pH}_{\mathrm{ua}}$ was lower $(7.16 \pm 0.10$ versus $7.20 \pm 0.08 ; p=0.000$ ) and the mean $\mathrm{BD}_{\mathrm{ua}}$ was higher $(5.10 \pm 3.84$ versus $4.12 \pm 3.74 \mathrm{mmol} / \mathrm{L} ; p=0.009)$ than in group $\mathrm{B}$. The newborns from group A were more likely to have $\mathrm{pH}_{\mathrm{ua}} \leq 7.00$, but not $\mathrm{BD}_{\mathrm{ua}} \geq 12.00 \mathrm{mmol} / \mathrm{L}$ ( $p=0.002$ and $p=0.721$, respectively) ( - Table 3 ).

All eight cases of $\mathrm{BD}_{\mathrm{ua}} \geq 12.00 \mathrm{mmol} / \mathrm{L}$ in group $\mathrm{A}$ also had $\mathrm{pH}_{\mathrm{ua}} \leq 7.00$. Considering the total cohort, newborns with $\mathrm{pH}_{\mathrm{ua}} \leq 7.00$ were more likely to have $\mathrm{BD}_{\text {ua }}$ $\geq 12.00 \mathrm{mmol} / \mathrm{L}(p=0.000)$ and vice-versa $(p=0.000)$. There were no statistically significant differences between the groups $\mathrm{pH}_{\mathrm{ua}} \leq 7.00$ and $\mathrm{pH}_{\mathrm{ua}}>7.00$ and the groups $\mathrm{BD}_{\text {ua }}$ $\geq 12.00 \mathrm{mmol} / \mathrm{L}$ and $\mathrm{BD}_{\mathrm{ua}}<12.00 \mathrm{mmol} / \mathrm{L}$ regarding any of the potentially confounders analyzed. Among all newborns, 26 in group A and 23 in group B had at least one adverse neonatal outcome $(14.9 \%$ versus $9.1 \% ; \quad p=0.065)$ (-Table 4).

The only neonatal outcome that had a statistically significant difference between the groups (3.4\% versus $0.4 \%$, $p=0.020$ ) was 5 ' AS $\leq 7$. In the total cohort, there was only one case of HIE, which occurred in group B. It was a 40-week pregnancy, with the diagnosis of gestational hypertension and oligohydramnios, ending in a vacuum-assisted delivery due to a second stage arrest of labor. The 3,150 g male newborn had a 1' $\mathrm{AS}=3$ and a 5' $\mathrm{AS}=7$. The $\mathrm{pH}_{\mathrm{ua}}$ was 6.85 and the $\mathrm{BD}_{\mathrm{ua}}$ was 18.90 . The results of the univariate regression analyses of association between neonatal outcomes and $\mathrm{pH}_{\mathrm{ua}} \leq 7.00$ or $\mathrm{BD}_{\mathrm{ua}} \geq 12.00 \mathrm{mmol} / \mathrm{L}$ showed five significant associations (- Table 5):

1. $\mathrm{pH}_{\mathrm{ua}} \leq 7.00$ and 1 ' $\mathrm{AS} \leq 4$ (total cohort: $\mathrm{OR}=9.57 ; 95 \% \mathrm{CI}$ : 2.33-39.25; $p=0.009)$;

2. $\mathrm{pH}_{\mathrm{ua}} \leq 7.00$ and $5, \mathrm{AS} \leq 7$ (total cohort: $\mathrm{OR}=10.83 ; 95 \%$ CI: $1.94-60.40 ; p=0.028)$;

Table 3 Descriptive statistics of neonatal outcome predictors

\begin{tabular}{|c|c|c|c|c|c|c|c|}
\hline \multirow[t]{2}{*}{ Variables } & \multicolumn{2}{|c|}{ Total cohort } & \multicolumn{2}{|c|}{ Group A } & \multicolumn{2}{|c|}{ Group B } & \multirow[b]{2}{*}{ p-value } \\
\hline & $n$ & $\%$ & $n$ & $\%$ & $n$ & $\%$ & \\
\hline $\mathrm{pH}_{\text {uа }}$ & & & & & & & 0.002 \\
\hline$\leq 7.00$ & 17 & 4.0 & 13 & 7.4 & 4 & 1.6 & \\
\hline$>7.00$ & 411 & 96.0 & 162 & 92.6 & 249 & 98.4 & \\
\hline $\mathrm{BD}_{\text {ча }}(\mathrm{mmol} / \mathrm{L})$ & & & & & & & 0.721 \\
\hline$\geq 12.00$ & 8 & 1.9 & 4 & 2.3 & 4 & 1.6 & \\
\hline$<12.00$ & 420 & 98.1 & 171 & 97.7 & 249 & 98.4 & \\
\hline
\end{tabular}

Abbreviations: $\mathrm{BD}_{\text {ua, }}$ umbilical artery blood deficit; $\mathrm{pH}_{\text {ua, }}$ umbilical artery $\mathrm{pH}$. 
Table 4 Descriptive statistics of neonatal outcomes

\begin{tabular}{|c|c|c|c|c|c|c|c|}
\hline \multirow[t]{2}{*}{ Variables } & \multicolumn{2}{|c|}{ Total cohort } & \multicolumn{2}{|c|}{ Group A } & \multicolumn{2}{|c|}{ Group B } & \multirow[b]{2}{*}{ p-value } \\
\hline & $n$ & $\%$ & $n$ & $\%$ & $n$ & $\%$ & \\
\hline \multicolumn{7}{|l|}{ Adverse neonatal outcome } & \multirow[t]{3}{*}{0.065} \\
\hline No & 379 & 88.6 & 149 & 85.1 & 230 & 90.9 & \\
\hline Yes & 49 & 11.4 & 26 & 14.9 & 23 & 9.1 & \\
\hline \multicolumn{7}{|l|}{ 1'AS } & \multirow[t]{3}{*}{0.078} \\
\hline$\leq 4$ & 416 & 97.2 & 8 & 4.6 & 4 & 1.6 & \\
\hline$>4$ & 12 & 2.8 & 167 & 95.4 & 249 & 98.4 & \\
\hline \multicolumn{7}{|l|}{ 5'AS } & \multirow[t]{3}{*}{0.020} \\
\hline$\leq 7$ & 421 & 98.4 & 6 & 3.4 & 1 & 0.4 & \\
\hline$>7$ & 7 & 1.6 & 169 & 96.6 & 252 & 99.6 & \\
\hline \multicolumn{7}{|l|}{ ANH } & \multirow[t]{3}{*}{0.189} \\
\hline No & 408 & 95.3 & 164 & 93.7 & 244 & 96.4 & \\
\hline Yes & 20 & 4.7 & 11 & 6.3 & 9 & 3.6 & \\
\hline \multicolumn{7}{|l|}{$\mathrm{HIE}$} & \multirow[t]{3}{*}{1.000} \\
\hline No & 427 & 99.8 & 175 & 100.0 & 252 & 99.6 & \\
\hline Yes & 1 & 0.2 & 0 & 0.0 & 1 & 0.4 & \\
\hline \multicolumn{7}{|l|}{ Neonatal seizures } & \multirow[t]{3}{*}{1.000} \\
\hline No & 426 & 99.5 & 174 & 99.4 & 252 & 99.6 & \\
\hline Yes & 2 & 0.5 & 1 & 0.6 & 1 & 0.4 & \\
\hline \multicolumn{7}{|l|}{ RDS I } & \multirow[t]{3}{*}{0.057} \\
\hline No & 417 & 97.4 & 167 & 95.4 & 250 & 98.8 & \\
\hline Yes & 11 & 2.6 & 8 & 4.6 & 3 & 1.2 & \\
\hline \multicolumn{7}{|l|}{ RDS II } & \multirow[t]{3}{*}{0.203} \\
\hline No & 412 & 96.3 & 9 & 5.1 & 246 & 97.2 & \\
\hline Yes & 16 & 3.7 & 166 & 94.9 & 7 & 2.8 & \\
\hline \multicolumn{8}{|c|}{ Meconium aspiration syndrome } \\
\hline No & 424 & 99.1 & 173 & 98.9 & 251 & 99.2 & \multirow[t]{2}{*}{1.000} \\
\hline Yes & 4 & 0.9 & 2 & 1.1 & 2 & 0.8 & \\
\hline \multicolumn{8}{|l|}{ Neonatal bradycardia } \\
\hline No & 423 & 98.8 & 174 & 99.4 & 249 & 98.4 & \multirow[t]{2}{*}{0.653} \\
\hline Yes & 5 & 1.2 & 1 & 0.6 & 4 & 1.6 & \\
\hline \multicolumn{7}{|l|}{ Neonatal sepsis } & \multirow[t]{3}{*}{1.000} \\
\hline No & 424 & 99.1 & 173 & 98.9 & 251 & 99.2 & \\
\hline Yes & 4 & 0.9 & 2 & 1.1 & 2 & 0.8 & \\
\hline
\end{tabular}

Abbreviations: 1' AS, first minute Apgar score; 5' AS, fifth minute Apgar score; ANH, acute neonatal hypoxia; HIE, hypoxic-ischemic encephalopathy; RDS, respiratory distress syndrome.

3. $\mathrm{pH}_{\mathrm{ua}} \leq 7.00$ and $\mathrm{ANH}$ (total cohort: $\mathrm{OR}=7.60 ; 95 \% \mathrm{CI}$ : $2.23-25.91 ; p=0.006$; group $\mathrm{B}: \mathrm{OR}=34.57 ; 95 \% \mathrm{CI}$ : 4.24-282.06; $p=0.007)$;

4. $\mathrm{BD}_{\mathrm{ua}} \geq 12.00 \mathrm{mmol} / \mathrm{L}$ and 1 ' $\mathrm{AS} \leq 4$ (total cohort: $\mathrm{OR}=27.40$; 95\% CI: 5.66-132.54; $p=0.001$; group A: OR = 27.50; 95\% CI: 3.29-229.68; $p=0.011$ );

5. $\mathrm{BD}_{\mathrm{ua}} \geq 12.00 \mathrm{mmol} / \mathrm{L}$ and $\mathrm{ANH}$ (total cohort: $\mathrm{OR}=7.44$; 95\% CI: $1.40-39.49 ; p=0.049$ ).

In the total cohort, the univariate regression analysis of the association between these three neonatal outcomes and the possible confounding factors revealed that (-Table 6):

1. There was a statistically significant association between maternal multiparity and 1 'AS $\leq 4,5$ 'AS $\leq 7$ and $A N H$ (OR: 4.45; 95\% CI: 1.32-15.04; $p=0.022$; OR: 5.47; 95\% CI: 1.05-28.58; $p=0.037$; and OR: 2.74; 95\% CI: 1.11-6.77; $p=0.024$, respectively)

2. There was a statistically significant association between shoulder dystocia at birth and ANH (OR: 15.00; 95\% CI: 2.36-95.44; $p=0.019$ ). 
Table 5 Results of the univariate regression analyses for neonatal outcomes in newborns with pHua $\leq 7.00$ and BDua $\geq 12.00 \mathrm{mmol} / \mathrm{L}$

\begin{tabular}{|c|c|c|c|c|c|c|c|c|c|}
\hline \multirow[t]{2}{*}{ Variables } & \multicolumn{3}{|c|}{ Total cohort } & \multicolumn{3}{|c|}{ Group A } & \multicolumn{3}{|c|}{ Group B } \\
\hline & OR & $95 \% \mathrm{Cl}$ & p-value & OR & $95 \% \mathrm{Cl}$ & p-value & OR & $95 \% \mathrm{Cl}$ & p-value \\
\hline \multicolumn{10}{|l|}{$\mathrm{pH}_{\mathrm{ua}} \leq 7.00$} \\
\hline $1^{\prime} \mathrm{AS} \leq 4$ & 9.57 & $2.33-39.25$ & 0.009 & 4.73 & $0.85-26.22$ & 0.111 & 27.33 & $2.17-344.29$ & 0.062 \\
\hline $5^{\prime} \mathrm{AS} \leq 7$ & 10.83 & $1.94-60.40$ & 0.028 & 2.62 & $0.28-24.23$ & 0.375 & n.a. & n.a. & 0.016 \\
\hline $\mathrm{ANH}$ & 7.60 & $2.23-25.91$ & 0.006 & 3.09 & $0.59-16.09$ & 0.191 & 34.57 & $4.24-282.06$ & 0.007 \\
\hline Neonatal seizures & n.a. & n.a. & 0.439 & n.a. & n.a. & 1.000 & n.a. & n.a. & 0.242 \\
\hline RDS I & 2.51 & $0.30-20.79$ & 0.363 & 1.85 & $0.21-16.26$ & 0.468 & n.a. & n.a. & 1.000 \\
\hline RDS II & 3.78 & $0.79-18.15$ & 0.128 & 4.03 & $0.75-21.74$ & 0.136 & n.a. & n.a. & 1.000 \\
\hline $\begin{array}{l}\text { Meconium } \\
\text { aspiration } \\
\text { syndrome }\end{array}$ & n.a. & n.a. & 1.000 & n.a. & n.a. & 1.000 & n.a. & n.a. & 1.000 \\
\hline $\begin{array}{l}\text { Neonatal } \\
\text { bradycardia }\end{array}$ & 4.17 & $0.46-37.65$ & 0.210 & n.a. & n.a. & 1.000 & 3.92 & $0.40-38.18$ & 0.322 \\
\hline Neonatal sepsis & 3.12 & $0.32-30.19$ & 3.120 & n.a. & n.a. & 0.507 & 1.28 & $0.08-20.72$ & 1.000 \\
\hline \multicolumn{10}{|l|}{$\mathrm{BD}_{\text {ua }} \geq 12.00 \mathrm{mmol} / \mathrm{L}$} \\
\hline $1^{\prime} \mathrm{AS} \leq 4$ & 27.40 & $5.66-132.54$ & 0.001 & 27.50 & $3.29-229.68$ & 0.011 & 27.33 & $2.17-344.29$ & 0.062 \\
\hline $5^{\prime}$ AS $\leq 7$ & 9.86 & $1.04-93.05$ & 0.125 & n.a. & n.a. & 0.016 & n.a. & n.a. & 1.000 \\
\hline ANH & 7.44 & $1.40-39.49$ & 0.049 & 5.37 & $0.51-56.36$ & 0.230 & 10.04 & $0.94-107.45$ & 0.136 \\
\hline Neonatal seizures & n.a. & n.a. & 1.000 & n.a. & n.a. & 1.000 & n.a. & n.a. & 1.000 \\
\hline RDS I & n.a. & n.a. & 1.000 & n.a. & n.a. & 1.000 & n.a. & n.a. & 1.000 \\
\hline RDS II & 3.86 & $0.45-33-37$ & 0.265 & 6.79 & $0.63-71.79$ & 0.192 & n.a. & n.a. & 1.000 \\
\hline $\begin{array}{l}\text { Meconium } \\
\text { aspiration } \\
\text { syndrome }\end{array}$ & n.a. & n.a. & 1.000 & n.a. & n.a. & 1.000 & n.a. & n.a. & 1.000 \\
\hline $\begin{array}{l}\text { Neonatal } \\
\text { bradycardia }\end{array}$ & n.a. & n.a. & 1.000 & n.a. & n.a. & 1.000 & n.a. & n.a. & 1.000 \\
\hline Neonatal sepsis & n.a. & n.a. & 1.000 & n.a. & n.a. & 1.000 & n.a. & n.a. & 1.000 \\
\hline
\end{tabular}

Abbreviations: 1' AS, first minute Apgar score; 5' AS, fifth minute Apgar score; ANH, acute neonatal hypoxia; $\mathrm{BD}_{\text {ча, }}$ umbilical artery blood deficit; $\mathrm{n}$.a.,

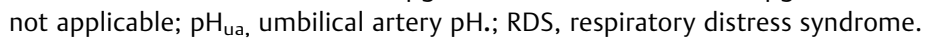

After the application of the logistic regression models, the conclusions were:

1. Belonging to group A did not affect the occurrence of 1' AS $\leq 4,5$ ' AS $\leq 7$, or ANH when compared with group B $(p=0.185 ; p=0.098$; and $p=0.600$, respectively);

2. There was a statistically significant impact of $\mathrm{pH}_{\mathrm{ua}} \leq 7.00$ in the occurrence of ANH (OR: 6.71; 95\% CI: 1.21-37.06; $p=0.029)$, but not in the occurrence of $1^{\prime}$ AS $\leq 4$ or of 5 ' AS $\leq 7$ ( $p=0.871$; and $p=0.130$, respectively);

3. Multiparous women had a statistically significant higher risk of delivering a newborn with 1 ' $\mathrm{AS} \leq 4$ and $\mathrm{ANH}$ (OR: 5.38; 95\% CI: $1.35-21.43 ; p=0.017$; and OR: 2.66 ; $95 \% \mathrm{CI}$ : $1.03-6.89 ; p=0.043$, respectively);

4. Women who had urologic problems during pregnancy had a statistically significantly higher risk of delivering a newborn with 5' AS $\leq 7$ (OR: 15.17; 95\% CI: 1.29-177.99; $p=0.030$ );

5. Shoulder dystocia represents a 15 times higher risk of ANH (OR: 14.82; 95\% CI: 2.20-99.60; $p=0.006$ ).

\section{Discussion}

The $\mathrm{pH}_{\text {ua }}$ seems to be a reliable marker for acute peripartum problems and a good predictor of adverse neonatal outcomes, as has been widely documented in the literature. ${ }^{1,2,4-6}$ The results of the present study support these concepts. In fact, the newborns with $\mathrm{pH}_{\text {ua }} \leq 7.00$ had a 9.57 times higher risk of 1' AS $\leq 4$, a 10.83 times higher risk of 5' AS $\leq 7$, and a 7.6 times higher risk of $\mathrm{ANH}$; and after the multivariate analysis, $\mathrm{pH}_{\mathrm{ua}} \leq 7.00$ remained as an independent predictor of $\mathrm{ANH}$, granting a 6.71 higher risk.

There is no consensus about the importance of $\mathrm{BD}_{\mathrm{ua}}$ as an adverse outcome predictor. ${ }^{3,5,6,9}$ In the present study, the risk of 1'AS $\leq 4$ and of ANH was 27.4 and 7.44 higher for the newborns with $\mathrm{BD}_{\mathrm{ua}} \geq 12.00 \mathrm{mmol} / \mathrm{L}$, respectively; and after excluding the confounding factors, $\mathrm{BD}_{\mathrm{ua}} \geq 12.00 \mathrm{mmol} / \mathrm{L}$ remained an independent predictor of 1 'AS $\leq 4$, increasing its risk almost 52 times.

Shoulder dystocia is a well-known risk factor of neonatal hypoxia. Therefore, it is not surprising that it significantly 
Table 6 Results of the univariate regression analyses for confounding factors in newborns with 1' AS $\leq 4,5$ ' AS $\leq 7$ and ANH, in total cohort

\begin{tabular}{|c|c|c|c|c|c|c|c|c|c|}
\hline \multirow[t]{2}{*}{ Variables } & \multicolumn{3}{|c|}{$1 ' A S \leq 4$} & \multicolumn{3}{|c|}{$5^{\prime} A S \leq 7$} & \multicolumn{3}{|l|}{ ANH } \\
\hline & OR & $95 \% \mathrm{Cl}$ & p-value & OR & $95 \% \mathrm{Cl}$ & p-value & OR & $95 \% \mathrm{Cl}$ & p-value \\
\hline Study group & 2.98 & $0.88-10.06$ & 0.078 & 8.95 & $1.97-74.98$ & 0.020 & 1.82 & $0.74-4.49$ & 0.244 \\
\hline Maternal age & 1.24 & $0.37-4.18$ & 1.000 & 0.82 & $0.18-3.70$ & 1.000 & 1.15 & $0.45-2.94$ & 0.771 \\
\hline Parity & 4.45 & $1.32-15.04$ & 0.022 & 5.47 & $1.05-28.58$ & 0.037 & 2.74 & $1.11-6.77$ & 0.024 \\
\hline $\begin{array}{l}\text { Insulin treated } \\
\text { gestational diabetes }\end{array}$ & 2.010 & 0.246 & 0.424 & n.a. & n.a. & n.a. & n.a. & n.a. & n.a. \\
\hline $\begin{array}{l}\text { Non-insulin treated } \\
\text { gestational diabetes }\end{array}$ & n.a. & n.a. & n.a. & n.a. & n.a. & n.a. & n.a. & n.a. & n.a. \\
\hline Gestational hypertension & n.a. & n.a. & n.a. & n.a. & n.a. & n.a. & n.a. & n.a. & n.a. \\
\hline $\begin{array}{l}\text { Urologic problems } \\
\text { during pregnancy }\end{array}$ & 9.36 & $0.97-90.78$ & 0.133 & 17.36 & $1.68-179.44$ & 0.080 & 5.32 & $057-49.89$ & 0.214 \\
\hline Oligohydramnios & n.a. & n.a. & n.a. & n.a. & n.a. & n.a. & n.a. & n.a. & n.a. \\
\hline Gestational age at birth & 1.06 & $0.23-4.96$ & 1.000 & n.a. & n.a. & n.a. & 0.62 & $0.22-1.77$ & 0.368 \\
\hline Vacuum delivery & 0.39 & $0.11-1.30$ & 0.111 & 1.06 & $0.23-4.77$ & 1.000 & 0.63 & $0.26-1.56$ & 0.317 \\
\hline Forceps delivery & 2.77 & $0.58-13.27$ & 0.202 & 2.25 & $0.26-19.35$ & 0.401 & 2.49 & $0.69-9.03$ & 0.157 \\
\hline Cesarean section & 2.25 & $0.71-7.11$ & 0.205 & 0.88 & $0.17-4.57$ & 1.000 & 1.19 & $0.46-3.06$ & 0.715 \\
\hline Newborn's gender & 0.43 & $0.12-1.62$ & 0.202 & 0.53 & $0.10-2.74$ & 0.704 & 0.70 & $0.28-1.80$ & 0.460 \\
\hline Birthweight & n.a. & n.a. & n.a. & n.a. & n.a. & n.a. & n.a. & n.a. & n.a. \\
\hline Shoulder dystocia & 9.36 & $0.97-90.78$ & 0.133 & n.a. & n.a. & n.a. & 15.00 & $2.36-95.43$ & 0.019 \\
\hline Neonatal sepsis & n.a. & n.a. & n.a. & n.a. & n.a. & n.a. & n.a. & n.a. & n.a. \\
\hline
\end{tabular}

Abbreviations: 1' AS, first minute Apgar score; 5' AS, fifth minute Apgar score; ANH, acute neonatal hypoxia; n.a., not applicable.

increases the risk of ANH. Performing an UCBGA seems warranted in these situations.

Although there was an association between $\mathrm{pH}_{\mathrm{ua}} \leq 7.00$ and 1' AS $\leq 4$, as well as between $\mathrm{pH}_{\mathrm{ua}} \leq 7.00$ and 5' $\mathrm{AS} \leq 7$, belonging to group A did not affect the occurrence of 1 ' $A S \leq 4$ or of 5 'AS $\leq 7$. This fact can be explained by the findings of Sabol et al, ${ }^{1}$ which concluded that newborns with a reassuring Apgar score have a residual risk of neonatal acidemia. They also concluded that, in this rare setting, the acidemic newborns have worse outcomes when compared with their non-acidemic counterparts. ${ }^{1}$ These findings support the introduction of universal UCBGA as a valuable neonatal screening test for neonatal hypoxia and its consequences.

Finally, the present study has found two other things that neither were expected nor clear in the previous literature. The newborns from multiparous women had a 5.38 and a 2.66 times higher risk of having 1' $\mathrm{AS} \leq 4$ and $\mathrm{ANH}$, respectively, when compared with newborns from nulliparous women. One study of Mgaya et $\mathrm{al}^{14}$ also found an increased incidence of low Apgar scores in newborns from grand multiparas. These findings can indicate an increased risk of disturbances in the fetal oxygenation that would predispose fetuses to a lower oxygen reserve during labor, but more studies are necessary to understand and validate this association.

The only independent predictor for 5' AS $\leq 7$ in the present study was urologic problems during pregnancy, which granted a 15.17 times higher risk of this adverse outcome. This finding is difficult to understand in the light of the current knowledge.
The present study has the limitations of a retrospective cohort: not all of the confounding variables can be controlled, and the data collected relies on accurate patient files, except for the UCBGA. In the 56 cases excluded due to limited data, there were 2 cases of shoulder dystocia and 23 cases of nonreassuring fetal CTG patterns, which may have caused a bias. Another limitation of the present study is that the UCBGA was not performed in all deliveries, but this seems to be shared in the majority of UBCGA studies. Collecting umbilical cord blood samples in emergency situations, like placental abruption or non-reassuring CTG patterns is difficult. In this study 66 out of the 148 UCBGA that were excluded because of incomplete, non-valid or only one-vessel results ocurred in such emergency settings, which lead to an inevitable bias. The small cohort size can justify why the only significant associations found were between $\mathrm{pH}_{\text {ua }} \leq 7.00$ and 1 'AS $\leq 4$; between 5'AS $\leq 7$ and $\mathrm{ANH}$; and between $\mathrm{BD}_{\mathrm{ua}} \geq 12.00 \mathrm{mmol} / \mathrm{L}$ and 1 'AS $\leq 4$ and ANH. Because only one newborn had HIE and there were no deaths, it became impossible to assess the relationship between these outcomes and neonatal $\mathrm{pH}_{\mathrm{ua}} \leq 7.00$ or $\mathrm{BD}_{\mathrm{ua}} \geq 12.00 \mathrm{mmol} / \mathrm{L}$.

In the light of new evidence, the umbilical artery lactate level seems as a reliable outcome predictor of low Apgar score and of neurologic morbidity ${ }^{6,13}$ that is directly measured from blood ${ }^{3}$. It is association with medium and longterm neonatal outcomes can be adressed in future.

Some recent studies argue that the threshold for adverse neonatal outcomes is $\mathrm{pH}_{\mathrm{ua}} \leq 7.10 .^{7,8}$ In the cohort of the present 
study, if the $\mathrm{pH}_{\mathrm{ua}}$ threshold is changed from $\mathrm{pH}_{\mathrm{ua}} \leq 7.00$ to $\mathrm{pH}_{\mathrm{ua}}$ $\leq 7.10$, the number of acidemic neonates increases from 17 to 79 , so further studies can be designed to verify whether there is an association between $\mathrm{pH}_{\mathrm{ua}} \leq 7.10$ and other neonatal outcomes besides 1'AS $\leq 4$; 5'AS $\leq 7$, and $\mathrm{ANH}$.

Additional studies are necessary to understand if multiparity and urologic problems during pregnancy are true predictors of adverse neonatal outcome; and, if so, what are the responsible physiopathological mechanisms.

\section{Conclusion}

The $\mathrm{pH}_{\text {ua }}$ and the $\mathrm{BD}_{\mathrm{ua}}$ are predictors of adverse neonatal outcomes, and the UCBGA is a useful tool for screening newborns at risk. The meaning of low $\mathrm{pH}_{\mathrm{ua}}$ and high $\mathrm{BD}_{\mathrm{ua}}$ present in clinically healthy newborns with good Apgar scores remains to be determined, but the healthy acidemic newborns seem to have worse outcomes when compared with their non-acidemic counterparts. Therefore, universal UCBGA should be considered for all deliveries because it is an accurate screening test for neonatal hypoxia.

\section{Contributions}

Ferreira C. S. - elaboration of the database, data search, statistical analysis, and article writing, revision and approval. Melo A. - elaboration of the database, data search, and article revision and approval. Fachada A.H. - data search and article revision; Solheiro H. - data supply and search and article revision and approval; Martins N. N. - study design, elaboration of the database, and article revision and approval.

\section{Conflict of Interests}

The authors have no conflicts of interests to disclose.

\section{Acknowledgements}

The authors would like to thank the Clinical Pathology Department of the Centro Hospitalar Tondela-Viseu for its help in the UCBGA data collection and to Adriana Belo for her collaboration in the statistical analysis.

\section{References}

1 Sabol BA, Caughey AB. Acidemia in neonates with a 5-minute Apgar score of 7 or greater - What are the outcomes? Am J Obstet Gynecol 2016;215(04):486.e1-486.e6 Doi: 10.1016/j.ajog.2016.05.035
2 Malin GL, Morris RK, Khan KS. Strength of association between umbilical cord $\mathrm{pH}$ and perinatal and long term outcomes: systematic review and meta-analysis. BMJ 2010;340:c1471 Doi: 10.1136/ bmj.c1471

3 Knutzen L, Svirko E, Impey L. The significance of base deficit in acidemic term neonates. Am J Obstet Gynecol 2015;213(03):373. e1-373.e7 Doi: 10.1016/j.ajog.2015.03.051

4 Ahmadpour-Kacho M, Zahedpasha Y, Hagshenas M, Akbarian Rad Z, Sadat Nasseri B, Bijani A. Short term outcome of neonates born with abnormal umbilical cord arterial blood gases. Iran J Pediatr 2015;25(03):e174 Doi: 10.5812/ijp.25(3)2015.174

5 Georgieva A, Moulden M, Redman CW. Umbilical cord gases in relation to the neonatal condition: the EveREst plot. Eur J Obstet Gynecol Reprod Biol 2013;168(02):155-160 Doi: 10.1016/j. ejogrb.2013.01.003

6 Martí Gamboa S, Pascual Mancho J, Rodrigo Rodríguez M, Ruiz Sada J, Castán Mateo S. pH, base deficit or lactate. Which is better for predicting neonatal morbidity? J Matern Fetal Neonatal Med 2017;30(19):2367-2371 Doi: 10.1080/ 14767058.2016.1248936

7 Morgan JL, Casey BM, Bloom SL, McIntire DD, Leveno KJ. Metabolic acidemia in live births at 35 weeks of gestation or greater. Obstet Gynecol 2015;126(02):279-283 Doi: 10.1097/AOG.0000000000 000923

8 Yeh P, Emary K, Impey L. The relationship between umbilical cord arterial $\mathrm{pH}$ and serious adverse neonatal outcome: analysis of 51,519 consecutive validated samples. BJOG 2012;119(07): 824-831 Doi: 10.1111/j.1471-0528.2012.03335.x

9 Victory R, Penava D, Da Silva O, Natale R, Richardson B. Umbilical cord $\mathrm{pH}$ and base excess values in relation to adverse outcome events for infants delivering at term. Am J Obstet Gynecol 2004; 191(06):2021-2028

10 Low JA, Panagiotopoulos C, Derrick EJ. Newborn complications after intrapartum asphyxia with metabolic acidosis in the term fetus. Am J Obstet Gynecol 1994 Apr;170(04):1081-1087

11 Andres RL, Saade G, Gilstrap LC, et al. Association between umbilical blood gas parameters and neonatal morbidity and death in neonates with pathologic fetal acidemia. Am J Obstet Gynecol 1999;181(04):867-871 Doi: 10.1016/S0002-9378(99) 70316-9

12 Royal College of Obstetricians and Gynecologists, Royal College of Midwives, Royal College of Anaesthetists, Royal College of Paediatrics and Child Health. Safer Childbirth: Minimum Standards for the Organisation and Delivery of Care in Labour. London: RCOG; 2007

13 American Academy of Pediatrics. Neonatal encephalopathy and neurologic outcome, Second Edition: Report of the American College of Obstetricians and Gynecologists' Task Force on Neonatal Encephalopathy. Pediatrics 2014;133: e1482-e1488

14 Mgaya AH, Massawe SN, Kidanto HL, Mgaya HN. Grand multiparity: is it still a risk in pregnancy? BMC Pregnancy Childbirth 2013;13:241 Doi: 10.1186/1471-2393-13-241 